\title{
THE USER-PREFERRED OPTIMAL FLIGHT PARAMETERS IN AN ACTIVE NAVIGATIONAL SYSTEM IN A MULTI-ALTERNATIVE SITUATION
}

\author{
Andriy Viktorovich Goncharenko \\ National Aviation University, Aerospace Faculty, \\ Kosmonavta Komarova Avenue, Kyiv, 03058, Ukraine \\ andygoncharenco@yahoo.com • ORCID: 0000-0002-6846-9660
}

\begin{abstract}
The goal of this paper is to investigate the influence of the objectively existing effectiveness functions of an aircraft control system upon the control and managerial decision making process in the framework of the subjective entropy maximum princi-ple. The subjective analysis theory entropy paradigm makes it possible to consider the aircraft control system based upon personal preferences as an active system governed by an individual (active element of the control system) with the help of her/his individual subjective preferences optimal distributions obtained in conditions of operational multi-alternativeness and those operational alternatives the active system active element's individual subjective preferences uncertainty. The described ap-proach takes into account the simple two-alternative operational situation in regards with the objectively existing effectiveness functions, related to the aircraft control system, in the view of a controlled parameter and a combination of it with its rate as the ratio. The obtained expressions for the objective functional extremal functions of the effectiveness and preferences, as well as the subjective entropy of the alternatives preferences, illustrated in diagrams visualize the situation and allow taking a good choice. The ideas of the required proper governing, managing, and control methods choice optimization with respect to only 2 alternative objective effectiveness functions arguments might be simple; nevertheless, increasing the number of parameters and further complication of the problem setting will not change the principle of the problem solution.
\end{abstract}

Keywords: control, navigation, decision making, preferences, entropy theory.

\section{INTRODUCTION}

The traditional control science and theory is developed pretty well, however sometimes there is a necessity to consider the system of control and controlling process from the point of view of the subjective analysis theory [1]. In the official (synonymously it is also may be called the traditional) control theory its mathematical apparatus helps successfully solving a lot of principal types of problems of control such as description, analysis, and synthesis of linear and nonlinear, discrete and continuous, steady-state and dynamical controlling systems. 
The latest operational efficiency studies can be formulated in terms of the active system's problem [2]. It proposes a novel control logic $[1,2]$ his might be combined with the concept of subjective optimality theory [1] and definitely touches specific areas of a bigger general problem of optimal control techniques in aircraft (and other objects, systems, and processes) guidance. It also could be traced with more publications; the references of [3-5]: the newest papers dealing with the multi-alternativeness of the problems.

The same is to the radio flight support operational system [6] because it necessitates the estimation of quality parameters in the multi-optionality of the possible operational situations; and it ought to be optimal. It is obvious that application of the proposed approach to the systems with active human functioning, emerging research [7] shows the opportunities for socio-technical decision support in air navigation systems, leads to the ways of optimization stipulated by the needs of the effective structural interactions.

The crucial point of the cognitive [8] operational situations alternatives effectiveness functions uncertainty and, at the same time, improving the transportation safety as well as ground target search and tracking [9], cost effectiveness, and operational efficiency are also important to be considered through the prism of subjective analysis [1].

Concerning active systems control [1] (it seems untraditional or unofficial control theory since this branch of the science is still quite a newly emerging so far), the most important feature of the theory is the consideration of the ruling person (subject, active element) of the control system [1, pp. 9-21]. And the cornerstone of the theory is the principle of subjective optimality [1, Introduction, especially pp. 15-17].

In relation to the problems of the optimal control techniques in aircraft guidance and control development, its safety technologies, as well as smart navigation or artificial intelligence versus natural, it should be mentioned that the subjective individuals' preferences [1] also have to be reckoned with. The spectrum of considerations and applications could be infinitely wide, such as having been paid an attention to at the references [2-9]; it deals with the multi-alternativeness of the situations.

Navigation itself is a good field of the subjective analysis of the active systems control [1] application. In the variety of scientific papers and conferences reports it is covered in the vast majority of aspects, such as: trajectory planning and development [9], drone-based system for localization of people inside buildings [10], modern traffic interfaces [11], onboard radar disposition [12] and its signals identification using a neural network and pattern recognition methods [13], unmanned aerial vehicle optimal path planning [14] and road surface hazard warning system for vehicle drivers [15]. In this sense, the proposed hereinafter approach is also very close to those issues in the scientific problematic.

Here it is important to emphasize that throughout those aspects the foundation stone of the subjective analysis theory: Subjective Entropy Maximum Principle (SEMP), [1], which takes into account the uncertainty measure for the individuals' subjective preferences of available alternatives, makes it possible to optimally evaluate the subjective preferences with the explicit view functions.

Entropy approaches are very popular in sciences accordingly with the reference study presented in the conference proceedings [16]. In this paper the entropy paradigm in the view of SEMP [1], developed on the basis of the well-known Jaynes' principle [17-19], is going to be used for theoretical contemplations related with the navigational flight parameters.

One more thing to be highlighted is that SEMP [1], having mathematical expressions of preferences likewise in the research work [20], differs significantly from the axiomatic of [20] in the theoretical and philosophical approach. The point is that the ideology and concepts of SEMP [1], although being postulated of their existence, in actual fact are a theorem construction for the preferences rather than basically an axiom for a choice probabilities being adopted for the preferences [20].

The advantages of such approach were demonstrated in works [21-35]. 


\section{MATHEMATICAL MODELING AND DEVELOPED METHODS}

An active system operation or functioning, including aircraft, is schematically described with the traditional control system scheme being under the influence of the individuals' subjective preferences although.

The presence of a subject in the control system makes the dynamic control function, generated by the governor and influencing the object, be multi-alternatively modified in accordance with the subject's individual preferences $\pi\left(\sigma_{i}\right)$ somehow optimally distributed upon the set of $S_{a}$ of the achievable alternatives $\sigma_{i}$ considered by the individual at the moment of time $t$.

Here it should be emphasized that the difference of the proposed consideration from the traditional control system theory is that the subject's individual preferences $\pi\left(\sigma_{i}\right)$ sometimes drastically change the dynamically controlling function and it is not always and necessarily in the correct, proper form. The list of examples might be endless; one can mention just a few cases related with the notorious human factor in civil aviation when operating aircraft. The autopilot hardly ever fails and wrongly changes the flight configuration of the aircraft at normal flight conditions and situations. But because of the sensors failures or onboard instruments wrong showings the human-pilot gets nervous, due to communication with the co-pilot it might raise panic with the inevitable dramatically conclusion. The engine fuel governor will probably not go wrong just because of the fire signaling lamp starts flashing for some malfunctioning happened to the circuit and not the real fire. But the operator might, mistakenly identifying the trouble and being under the stress of the situation, distribute his/her preferences in such way that it might lead to the unneeded fire extinguishing system activation with the engine stop in flight and sad effect.

Therefore, it is proposed to model mathematically the following situation in the framework of SEMP $[1,21-35]$.

\section{Problem setting}

It is considered theoretically the two-alternative situation with the effectiveness functions taken in the view of a significant navigational parameter itself and a function constructed with it.

The operational objective (purpose) functional:

$$
\Phi_{\pi}=\int_{t_{1}}^{t_{2}}\left(-\sum_{i=1}^{N=2} \pi_{i}(t) \ln \pi_{i}(t)+\beta\left[\pi_{1}(t) x(t)+\alpha \pi_{2}(t) \frac{\dot{x}(t)}{x(t)}\right]+\gamma\left[\sum_{i=1}^{N=2} \pi_{i}(t)-1\right]\right) d t,
$$

where: $\beta$ is the endogenous parameter of the individual's psychic (cognitive) properties, which takes into account the importance "valuableness" of the subjectively preferred effectiveness function (the second under-integral member);

$x(t)$ is the objectively existing effectiveness function pertaining with the first alternative, being preferred with the individual's subjective preferences function of $\pi_{1}(t) ; \alpha$ is the one more endogenous parameter of the individual's psychic properties, which takes into assessment the subjective preference "preferableness" of the second alternative with respect to the individual's subjective preferences function of $\pi_{2}(t)$ compared to the first alternative preference function of $\pi_{1}(t)$, the coefficient of $\alpha$ also takes into account the difference in dimensions for the two alternatives objectively existing effectiveness functions, namely $x(t)$ and $\frac{\dot{x}(t)}{x(t)}$;

$\gamma$ is the third endogenous parameter of the subject, it stands for the purpose of the individual's subjective preferences functions of $\pi_{i}(t)$, normalizing condition. 


\section{Problem solution}

Designate the under-integral function of the objective functional of (1) as:

$$
R^{*}=-\sum_{i=1}^{N=2} \pi_{i}(t) \ln \pi_{i}(t)+\beta\left[\pi_{1}(t) x(t)+\alpha \pi_{2}(t) \frac{\dot{x}(t)}{x(t)}\right]+\gamma\left[\sum_{i=1}^{N=2} \pi_{i}(t)-1\right] .
$$

At the extremals:

$$
\pi_{1}^{0}(t), \quad \pi_{2}^{0}(t), \quad x^{0}(t)
$$

the necessary conditions for an extremum of the objective functional of (1) existence are the satisfaction of the system of the Euler-Lagrange equations:

$$
\frac{\partial R^{*}}{\partial \pi_{i}}-\frac{d}{d t} \frac{\partial R^{*}}{\partial \dot{\pi}_{i}}=0, \quad \frac{\partial R^{*}}{\partial x}-\frac{d}{d t} \frac{\partial R^{*}}{\partial \dot{x}}=0 .
$$

For the given problem setting, the under-integral function (2) of the objective functional of (1) does not depend upon $\dot{\pi}_{i}$, hence,

$$
\frac{\partial R^{*}}{\partial \dot{\pi}_{i}} \equiv 0, \quad \frac{d}{d t} \frac{\partial R^{*}}{\partial \dot{\pi}_{i}} \equiv 0,
$$

and the system of the equations of (4) gets the view of:

$$
\frac{\partial R^{*}}{\partial \pi_{i}}=0, \quad \frac{\partial R^{*}}{\partial x}-\frac{d}{d t} \frac{\partial R^{*}}{\partial \dot{x}}=0 .
$$

In accordance with the obtained conditions of the equations of (6), it yields for the preferences functions $\pi_{i}(t)$ figuring out in the functional of (1):

$$
\frac{\partial R^{*}}{\partial \pi_{1}}=-\ln \pi_{1}-1+\beta x+\gamma=0
$$

and

$$
\frac{\partial R^{*}}{\partial \pi_{2}}=-\ln \pi_{2}-1+\alpha \beta \frac{\dot{x}}{x}+\gamma=0
$$

From where:

$$
\pi_{1}=e^{-1+\beta x+\gamma}=e^{\gamma-1} e^{\beta x}, \quad \pi_{2}=e^{-1+\alpha \beta \frac{\dot{x}}{x}+\gamma}=e^{\gamma-1} e^{\alpha \beta \frac{\dot{x}}{x}} .
$$

And from normalizing conditions:

$$
\pi_{1}+\pi_{2}=1=e^{\gamma-1} e^{\beta x}+e^{\gamma-1} e^{\alpha \beta \frac{\dot{x}}{x}}=e^{\gamma-1}\left(e^{\beta x}+e^{\alpha \beta \frac{\dot{x}}{x}}\right)
$$

therefore 


$$
e^{\gamma-1}=\frac{1}{e^{\beta x}+e^{\alpha \beta \frac{\dot{x}}{x}}} .
$$

Thus, using the found relations of (10) and (11), one can get the dependencies for the individual's subjective preferences functions of (9) in the view of $\pi_{1}$ and $\pi_{2}$ upon $x$ and $\dot{x}$ :

$$
\pi_{1}=\frac{e^{\beta x}}{e^{\beta x}+e^{\alpha \beta \frac{\dot{x}}{x}}}, \quad \pi_{2}=\frac{e^{\alpha \beta \frac{\dot{x}}{x}}}{e^{\beta x}+e^{\alpha \beta \frac{\dot{x}}{x}}} .
$$

For the extremal of $x_{0}(t)$, from the system of (3), one can obtain correspondingly at $\beta \neq 0$.

$$
\begin{gathered}
\frac{\partial R^{*}}{\partial x}=\beta \pi_{1}-\frac{\alpha \beta \pi_{2} \dot{x}}{x^{2}}, \quad \frac{\partial R^{*}}{\partial \dot{x}}=\frac{\alpha \beta \pi_{2}}{x}, \\
\frac{d}{d t} \frac{\partial R^{*}}{\partial \dot{x}}=\alpha \beta\left(\frac{\dot{\pi}_{2} x-\pi_{2} \dot{x}}{x^{2}}\right) .
\end{gathered}
$$

Then:

$$
\begin{gathered}
\beta \pi_{1}-\frac{\alpha \beta \pi_{2} \dot{x}}{x^{2}}-\left[\alpha \beta\left(\frac{\dot{\pi}_{2} x-\pi_{2} \dot{x}}{x^{2}}\right)\right]=\beta \pi_{1}-\left[\alpha \beta\left(\frac{\dot{\pi}_{2} x}{x^{2}}\right)\right]=0 \\
\pi_{1}=\alpha\left(\frac{\dot{\pi}_{2}}{x}\right) .
\end{gathered}
$$

At the given problem setting for the second alternative individual's subjective preference function first complete derivative with respect to time:

$$
\dot{\pi}_{2}=\frac{d \pi_{2}}{d t}=\frac{\partial \pi_{2}}{\partial t}+\frac{\partial \pi_{2}}{\partial x} \dot{x}+\frac{\partial \pi_{2}}{\partial \dot{x}} \ddot{x} .
$$

Since the preferences functions do not depend upon time $t$ in the explicit view, then:

$$
\frac{\partial \pi_{2}}{\partial t} \equiv 0
$$

Hence, instead of (16) with taking into consideration condition of (17), one can use just:

$$
\dot{\pi}_{2}=\frac{\partial \pi_{2}}{\partial x} \dot{x}+\frac{\partial \pi_{2}}{\partial \dot{x}} \ddot{x}
$$

Where:

$$
\frac{\partial \pi_{2}}{\partial x}=\frac{-\alpha \beta \frac{\dot{x}}{x^{2}} e^{\alpha \beta \frac{\dot{x}}{x}}\left(e^{\beta x}+e^{\alpha \beta \frac{\dot{x}}{x}}\right)-e^{\alpha \beta \frac{\dot{x}}{x}}\left(\beta e^{\beta x}-\alpha \beta \frac{\dot{x}}{x^{2}} e^{\alpha \beta \frac{\dot{x}}{x}}\right)}{\left(e^{\beta x}+e^{\alpha \beta \frac{\dot{x}}{x}}\right)^{2}}=\frac{-\alpha \beta \frac{\dot{x}}{x^{2}} e^{\alpha \beta \frac{\dot{x}}{x}}\left(e^{\beta x}\right)-e^{\alpha \beta \frac{\dot{x}}{x}}\left(\beta e^{\beta x}\right)}{\left(e^{\beta x}+e^{\alpha \beta \frac{\dot{x}}{x}}\right)^{2}} .
$$


Thus for equation (19):

$$
\frac{\partial \pi_{2}}{\partial x}=-\beta \pi_{1} \pi_{2}\left(\alpha \frac{\dot{x}}{x^{2}}+1\right)
$$

And

$$
\frac{\partial \pi_{2}}{\partial \dot{x}}=\frac{\frac{\alpha \beta}{x} e^{\alpha \beta \frac{\dot{x}}{x}}\left(e^{\beta x}+e^{\alpha \beta \frac{\dot{x}}{x}}\right)-e^{\alpha \beta \frac{\dot{x}}{x}}\left(\frac{\alpha \beta}{x} e^{\alpha \beta \frac{\dot{x}}{x}}\right)}{\left(e^{\beta x}+e^{\alpha \beta \frac{\dot{x}}{x}}\right)^{2}}=\frac{\frac{\alpha \beta}{x} e^{\alpha \beta \frac{\dot{x}}{x}}\left(e^{\beta x}\right)}{\left(e^{\beta x}+e^{\alpha \beta \frac{\dot{x}}{x}}\right)^{2}} .
$$

Therefore for equation (21) the proposed approach yields:

$$
\frac{\partial \pi_{2}}{\partial \dot{x}}=\frac{\alpha \beta}{x} \pi_{1} \pi_{2} .
$$

Now, substituting the obtained expressions of (20) and (22) for their corresponding values into the complete derivative equation (18) satisfactorily for the presented problem setting, one can have:

$$
\dot{\pi}_{2}=\frac{\alpha \beta}{x} \pi_{1} \pi_{2} \ddot{x}-\beta \pi_{1} \pi_{2}\left(\alpha \frac{\dot{x}}{x^{2}}+1\right) \dot{x} .
$$

Substituting the result of (23) for its corresponding value into the second equation of (15), it gives:

$$
\pi_{1}=\alpha\left[\frac{\alpha \beta}{x^{2}} \pi_{1} \pi_{2} \ddot{x}-\beta \pi_{1} \pi_{2}\left(\frac{\alpha \dot{x}+x^{2}}{x^{3}}\right) \dot{x}\right] .
$$

Canceling in the expression of $(24)$ for $\pi \neq 0$, one can get:

$$
1=\alpha\left[\frac{\alpha \beta x \pi_{2} \ddot{x}-\beta \pi_{2}\left(\alpha \dot{x}+x^{2}\right) \dot{x}}{x^{3}}\right] .
$$

And from (25) at $x \neq 0$.

$$
\ddot{x}=\frac{\frac{x^{3}}{\alpha}+\beta \pi_{2}\left(\alpha \dot{x}+x^{2}\right) \dot{x}}{\alpha \beta x \pi_{2}} .
$$

Substituting into equation (26) the corresponding expression (12) obtained for the individual's subjective preference of the second alternative $\pi_{2}$ and performing the needed transformations, one can have for $x(t)$ :

$$
\ddot{x}=\frac{x^{2}\left(e^{\beta\left(x-\alpha \frac{\dot{x}}{x}\right)}+1\right)}{\alpha^{2} \beta}+\frac{\left(\alpha \dot{x}+x^{2}\right) \dot{x}}{\alpha x} .
$$




\section{Numerical experiment}

In order to make the developed approach (1) - (27) more visible, it is conducted the following computer simulation.

The calculation experimental data have the next values:

$\alpha=9 \cdot 10^{2} ; \beta=-3 \cdot 10^{-2} ; t=[0 \ldots 200]$ conditional units (CU) of time; $x\left(t_{0}=0\right)=1 \cdot 10^{-2} \mathrm{CU}$ of the controlled parameter; $\dot{x}\left(t_{0}=0\right)=1 \cdot 10^{-3} \mathrm{CU}$ of the controlled parameter / CU of time.

\section{RESULTS AND DISCUSSION}

\section{Analysis of the obtained results}

The results of the modeling with the mentioned above numerical data are shown in Figures 1-4.

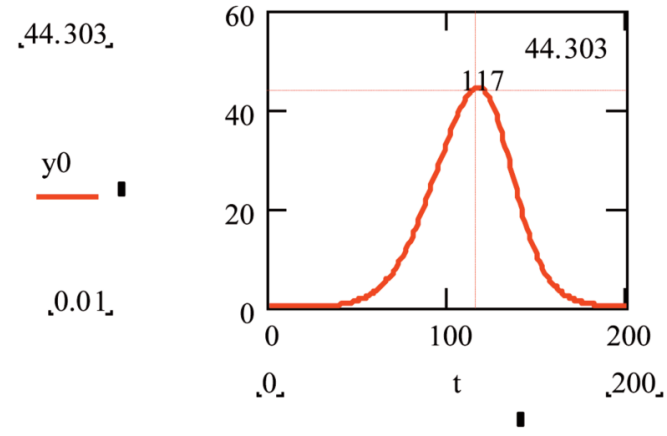

Fig. 1. Extremal of the controlled parameter at the presence of the Subject in the active control system.

In Figure 1 it is depicted y0 standing for the extremal of $x^{0}(t)(3)$ of the controlled parameter of $x(t)$.
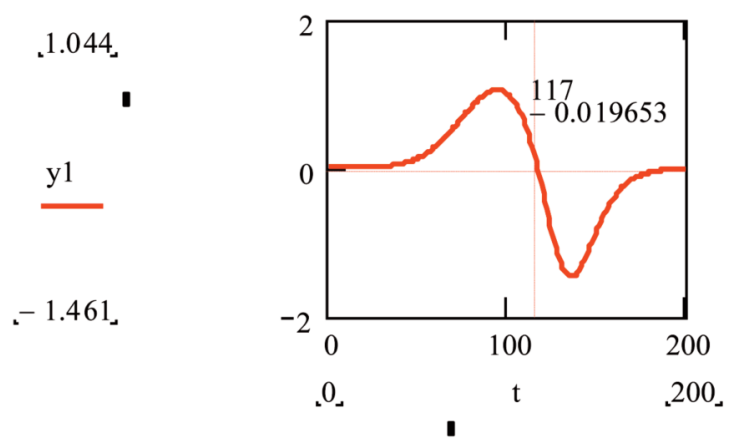

Fig. 2. Extremal of the rate of the controlled parameter (control) at the presence of the Subject in the active control system.

In Figure $2 \mathrm{y} 1$ is standing for the control (rate of the controlled parameter) of $\dot{x}(t)$.

The curves of y0 and y 1 plotted in the diagrams portrayed in Figures 1 and 2 are obtained as the solution to the ordinary differential equation of the second order (Euler-Lagrange equation) (27) for the extremals of $x(t)$ and $\dot{x}(t)$ at the indicated above initial conditions. 
The corresponding to the alternatives individual's subjective preferences functions in the considered circumstances are shown in Figure 3.

Here, in Figure 3, $\pi 1_{\mathrm{i}}$ and $\pi 2_{\mathrm{i}}$ designate the control system Subject's individual preferences $\pi_{1}^{0}(t)$ and $\pi_{2}^{0}(t)$ of (3), calculated by the corresponding equations of (12) for $\pi_{1}(t)$ and $\pi_{2}(t)$, distributed optimally in accordance with the uncertainty of the multi-alternative operational situation. The uncertainty of the preferences $\pi_{1}(t)$ and $\pi_{2}(t)$ is taken into account by the entropy member of the objective operational functional (1) (the first under-integral member of (1) and (2) equations).

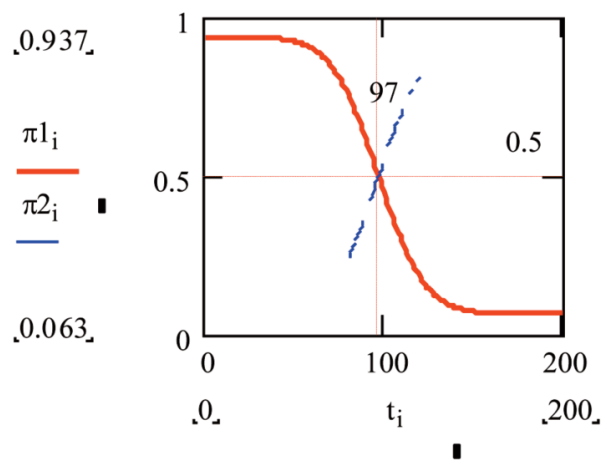

Fig. 3. Extremal of the individual Subject's preferences in the active control system.

The subjective entropy itself is shown in Figure 4.

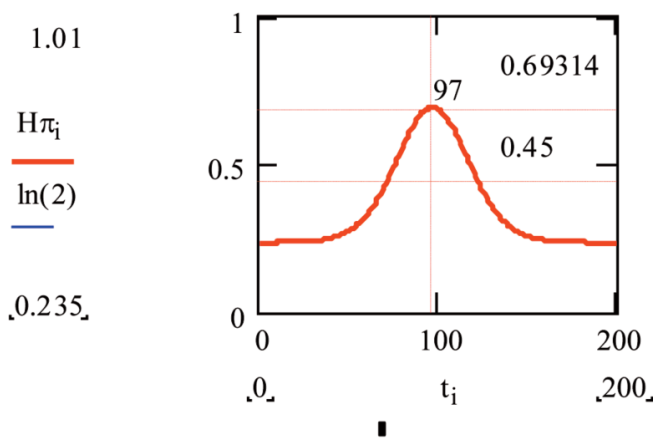

Fig. 4. Subjective entropy of the individual preferences accordingly to the attainable alternatives for the Subject in the active control system.

\section{DISCUSSION}

It is considered a certain kind of a hybrid combination of the Gibbs-Jaynes principle [17-19] with the classical theory of calculus of variations embodied in monograph [1], implemented in works [21-27], and proposed to application for aircraft control systems in aspects reflected in [2-15].

The influence of, let us say, the distance to the target: $x(t)$ (or some kind of a generalized coordinate) and its rate $\dot{x}(t)$ in its ratio to the specified coordinate: $\frac{\dot{x}(t)}{x(t)}$ is proposed to be modeled through 
the contents of the alternatives taken into consideration, objective functional construction, and endogenous parameters of $\alpha$ and $\beta$ plausible values.

Traditional view entropy of the preferences does not allow understanding to which alternative the Subject (active element) of the aircraft control system is inclined (see Fig. 4). For that purpose there is a hybrid combined relative pseudo-entropy function proposed, developed, and discussed in the dissertation by the author [http://er.nau.edu.ua:8080/handle/NAU/22359, pp. 41-49, (1.6-1.9), pp. 72-84, (2.19)].

After the climax with the maximal uncertainty (see Fig. 4), corresponding values are $t \approx 97 \mathrm{CU}$ of time and $\ln (2) \approx 0.69314$, this means the subjective preferences are $\pi_{1}(t)=\pi_{2}(t)=0.5$ (see Fig. 3), the traditional entropy begins decreasing, which implies that the Subject starts getting certain in regards with the achievable alternatives. However, it is not clear to the "good" or "bad" alternative.

Therefore, the investigations in the context of the hybrid combined relative pseudo-entropy function have to be continued. Compared to the case studied in [http://er.nau.edu.ua:8080/handle/NAU/22359, pp. 42-49, Figures 1.2-1.5] the aircraft control in the style of (1) - (27) and with the mentioned above calculation experimental data leads to a bit slower control decision making. For the individual's subjective entropy maximum this is $t \approx 97 \mathrm{CU}$ of time in the presented paper consideration and $t>65 \mathrm{CU}$ of time in the case discussed in dissertation [, p. 49, Figure 1.5]. But here it is much sharper (see Fig. 4).

The integral of subjective entropy in the objective functional (1) has a meaning of the volume of the uncertainty pressing upon the Subject during the period of a decision making (integration). Such contemplation also follows the statement about the mean uncertainty value over the period of consideration [1]. The exceeding value of the volume of uncertainty may lead to psychological stress or conflict behavior of the control system's active element. It is visible in the vicinity of the entropy climax (see Fig. 4). For the represented in this paper numerical experiment results, it is the time interval approximately $73<t<121 \mathrm{CU}$ of time in case of the subjective entropy threshold is about 0.45 (see Fig. 4).

It is because of that the accumulated through the time volume of uncertainty becomes unbearable for the individual and she/he is forced to come to a conclusion.

The proof is that the conducted numerical simulation clearly evidences that the prolongation of the time interval for a decision making (integration), at the other unchanged or equal conditions, might result in a decrease of the entropy below the decision making threshold at some moment (or before some moment). For the given paper simulation results, it makes $t<72$ and $t>122 \mathrm{CU}$ of time in case of the subjective entropy threshold is about 0.45 (see Fig. 4). However, the acquired certainty level, being lower than the decision making threshold 0.45 , not always guarantee the correct choice, which also was shown in the manuscript of [http://er.nau.edu.ua:8080/handle/NAU/22359, p. 49, Figure 1.5].

\section{CONCLUSIONS}

Conditions of uncertainty embodied in the corresponding entropies are crucial to both aspects of the aircraft control system in the active control systems: adequate assessment of objective parameters indications through their proper effectiveness functions and individual's subjective preferences functions optimal distributions.

The pressure of the volume of uncertainty, mounting up during the time of consideration in combination with the endogenous parameters of the person's psych, causes the terminal choice for the alternative which might be wrong, the traditional view entropy, alas, does not highlight that although.

The preferences functions give the possibility of the considered multi-alternative situation optimal active aircraft controlling system control assessment with respect to the preferences entropy uncertainty measure.

In further research, it should be considered some other effectiveness functions and their variables, being subjected to constraints. In addition, it would be useful to find more other combinations of effectiveness functions pertaining with the multi-alternative situation. Implementation of the hybrid combined relative pseudo-entropy function should bring new theoretical results and applicable areas of the subjective analysis entropy paradigm. 


\section{ACKNOWLEDGEMENTS}

The data supporting the results reported in the published article can be found in the references listed and wherever the approach is applicable. It is described in the paper.

The research and publication of the article is not funded by any financially supporting body.

\section{REFERENCES}

[1] Kasianov, V., 2013, Subjective entropy of preferences. Subjective analysis, Institute of Aviation, Warsaw, Poland, ISBN 978-83-63539-08-5.

[2] Kasjanov, V. and Szafran, K., 2015, "Some hybrid models of subjective analysis in the theory of active systems", Transactions of the Institute of Aviation, 3(240), pp. 27-31. $10.5604 / 05096669.1194963$

[3] Pagowski, Z. T. and Szafran, K., 2014, "Ground effect inter-modal fast sea transport", The International Journal on Marine Navigation and Safety of Sea Transportation, 8(2), pp. 317320. 10.12716/1001.08.02.18

[4] Szafran K., 2014, "Flight safety - the principle of maximum entropy," Safety on land, sea and air in the 21st century, 1, pp. 247-251, ISBN 978-83-61520-02-3, (in Polish).

[5] Szafran, K. and Kramarski, I., 2015, "Safety of navigation on the approaches to the ports of the republic of Poland on the basis of the radar system on the aerostat platform", International Journal on Marine Navigation and Safety of Sea Transportation, 9(1), pp. 129-134. 10.12716/1001.09.01.16

[6] Solomentsev, O., Zaliskyi, M. and Zuiev, O., 2016, "Estimation of quality parameters in the radio flight support operational system," Aviation, 20(3), pp. 123-128.

[7] Shmelova, T., Sikirda, Y., Rizun, N., Salem, A.-B. M. and Kovalyov, Y. N., 2017, Socio-Technical Decision Support in Air Navigation Systems: Emerging Research and Opportunities, International Publisher of Progressive Information Science and Technology Research, Pennsylvania, USA.

[8] Szafran, K., 2014, "Traction vehicle operator safety - laboratory dynamic", Logistyka, 6, pp. 192197, (in Polish).

[9] Krzysztofik, I. and Koruba, Z., 2014, 'Mathematical model of movement of the observation and tracking head of an unmanned aerial vehicle performing ground target search and tracking", Journal of Applied Mathematics, Special Issue (2014). 10.1155/2014/934250.

[10] Kaniewski, P. and Kraszewski, T., 2018, "Drone-based system for localization of people inside buildings," in Proceedings of the IEEE 14th International Conference on Advanced Trends in Radioelectronics, Telecommunications and Computer Engineering (TCSET-2018), S1: Radar systems, satellite communication, navigation, positioning systems, monitoring, pp. 178-185, IEEE, LvivSlavske, Ukraine.

[11] Kelner, J. M., Uljasz, B. and Nowosielski, L., 2018, "BER measurements in the evaluation of operation correctness of VSAT modem traffic interfaces," in Proceedings of the IEEE 14th International Conference on Advanced Trends in Radioelectronics, Telecommunications and Computer Engineering (TCSET-2018), S1: Radar systems, satellite communication, navigation, positioning systems, monitoring, pp. 161-165, IEEE, Lviv-Slavske, Ukraine.

[12] Łabowski, M. and Kaniewski, P., 2018, "A Method of Swath Calculation for Side-looking Airborne Radar," in Proceedings of the IEEE 14th International Conference on Advanced Trends in Radioelectronics, Telecommunications and Computer Engineering (TCSET-2018), S1: Radar systems, satellite communication, navigation, positioning systems, monitoring, pp. 166-177, IEEE, LvivSlavske, Ukraine.

[13] Matuszewski, J., 2018, "Radar signal identification using a neural network and pattern recognition methods," in Proceedings of the IEEE 14th International Conference on Advanced Trends in 
Radioelectronics, Telecommunications and Computer Engineering (TCSET-2018), S1: Radar systems, satellite communication, navigation, positioning systems, monitoring, pp. 249-253, IEEE, LvivSlavske, Ukraine, February 2018.

[14] Konatowski, S. and Pawłowski, P., 2018, "Ant Colony Optimization algorithm for UAV path planning," in Proceedings of the IEEE 14th International Conference on Advanced Trends in Radioelectronics, Telecommunications and Computer Engineering (TCSET-2018), S2: Information systems and technologies, computer-aided design, pp. 146-151, IEEE, Lviv-Slavske, Ukraine, February 2018.

[15] Konatowski, S. and Gołgowski, M., 2018, "Road surface hazard warning system for vehicle drivers," in Proceedings of the IEEE 14th International Conference on Advanced Trends in Radioelectronics, Telecommunications and Computer Engineering (TCSET-2018), S4: Electronics, photonics and innovative optical technologies: systems and devices, micro- and nanotechnologies, pp. 145-149, IEEE, Lviv-Slavske, Ukraine, February 2018.

[16] Ma F. C., Lv, P. H. and Ye, M., 2012, Study on Global Science and Social Science Entropy Research Trend, 2012 IEEE fifth international conference on advanced computational intelligence (ICACI), October 18-20, Nanjing, Jiangsu, China, pp. 238-242.

[17] Jaynes, E. T., 1957, "Information theory and statistical mechanics”, Physical review, 106(4), pp. 620-630.

[18] Jaynes, E. T., 1957, "Information theory and statistical mechanics. II", Physical review, 108(2), pp. 171-190.

[19] Jaynes, E. T., 1982, "On the rationale of maximum-entropy methods", Proceedings of the IEEE, Vol. 70, pp. 939-952.

[20] Zamfirescu, C. B., Duta, L. and Iantovics, B., 2010, ”On investigating the cognitive complexity of designing the group decision process", Studies in Informatics and Control 19(3), pp. 263-270.

[21] Goncharenko, A. V., 2018, "Airworthiness support measures analogy to the prospective roundabouts alternatives: theoretical aspects," Journal of Advanced Transportation, Article ID 9370597. $10.1155 / 2018 / 9370597$.

[22] Goncharenko, A. V., 2018, "A multi-optional hybrid functions entropy as a tool for transportation means repair optimal periodicity determination," Aviation, 22(2), pp. 60-66.

10.3846/aviation.2018.5930.

[23] Goncharenko, A. V., 2018, "Development of a theoretical approach to the conditional optimization of aircraft maintenance preference uncertainty," Aviation, 22(2), pp. 40-44.

10.3846 /aviation.2018.5929

[24] Goncharenko, A. V., 2018, "Optimal controlling path determination with the help of hybrid optional functions distributions," Radio Electronics, Computer Science, Control, 1(44), pp. 149-158. 10.15588/1607-3274-2018-1-17.

[25] Goncharenko, A. V., 2018, "Aeronautical and aerospace materials and structures damages to failures: theoretical concepts," International Journal of Aerospace Engineering, Article ID 4126085. $10.1155 / 2018 / 4126085$.

[26] Goncharenko, A. V., 2017, "Aircraft operation depending upon the uncertainty of maintenance alternatives," Aviation, (21)4, pp. 126-131. 10.3846/16487788.2017.1415227.

[27] Goncharenko, A. V., 2017, "Optimal UAV maintenance periodicity obtained on the multi-optional basis," Proceedings of the IEEE 4th International Conference on Actual Problems of Unmanned Aerial Vehicles Developments (APUAVD), pp. 65-68, IEEE, Kyiv, Ukraine, October 2017.

[28] Goncharenko, A. V., 2019, "Relative pseudo-entropy functions and variation model theoretically adjusted to an activity splitting," Proceedings of the 9th International Conference on Advanced Computer Information Technologies (ACIT'2019), pp. 52-55, Ceske Budejovice, Czech Republic, June 2019. 
[29] Goncharenko, A. V., 2018, "Active systems communicational control assessment in multialternative navigational situations," in Proceedings of the IEEE 5th International Conference on Methods and Systems of Navigation and Motion Control (MSNMC), pp. 254-257, IEEE, Kyiv, Ukraine, October 2018.

[30] Goncharenko, A. V., 2018, "Multi-optional hybrid effectiveness functions optimality doctrine for maintenance purposes," Proceedings of the IEEE 14th International Conference on Advanced Trends in Radioelectronics, Telecommunications and Computer Engineering (TCSET-2018), S8: Quality, reliability and diagnostics of electronic and information systems and devices, pp. 771-775, IEEE, Lviv-Slavske, Ukraine, February 2018.

[31] Goncharenko, A. V., 2018, "An entropy model of the aircraft gas turbine engine blades restoration method choice," Proceedings of the International Conference on Advanced Computer Information Technologies (ACIT'2018), pp. 2-5, Ceske Budejovice, Czech Republic, June 2018.

[32] Goncharenko, A. V., 2016, "Several models of artificial intelligence elements for aircraft control," Proceedings of the IEEE 4th International Conference on Methods and Systems of Navigation and Motion Control (MSNMC), pp. 224-227, IEEE, Kyiv, Ukraine, October 2016.

[33] Goncharenko, A. V., 2015, "Applicable aspects of alternative UAV operation," Proceedings of the IEEE 3rd International Conference on Actual Problems of Unmanned Aerial Vehicles Developments (APUAVD), pp. 316-319, IEEE, Kyiv, Ukraine, October 2015.

[34] Goncharenko, A. V., 2014, "Navigational alternatives, their control and subjective entropy of individual preferences," in Proceedings of the IEEE 3rd International Conference on Methods and Systems of Navigation and Motion Control (MSNMC), pp. 99-103, IEEE, Kyiv, Ukraine, October 2014.

[35] Goncharenko, A. V., 2013, "Expediency of unmanned air vehicles application in the framework of subjective analysis," Proceedings of the IEEE 2nd International Conference on Actual Problems of Unmanned Aerial Vehicles Developments (APUAVD), pp. 129-133, IEEE, Kyiv, Ukraine, October 2013.

\section{PREFERENCJE PILOTA - OPERATORA PRZY OPTYMALNYM WYBORZE ZE ZBIORU WIELU ALTERNATYW PARAMETRÓW LOTU W AKTYWNYM SYSTEMIE NAWIGACYJNYM}

\section{Abstrakt}

Celem tej publikacji jest zbadanie wpływu obiektywnie istniejących funkcji skuteczności systemu kontroli statku powietrznego na proces kontroli i podejmowania decyzji zarządczych w ramach subiektywnej zasady maksymalnej entropii. Paradygmat entropii teorii subiektywnej umożliwia rozważenie systemu sterowania samolotem opartego na osobistych preferencjach jako systemu aktywnego zarządzanego przez jednostkę (aktywny element systemu sterowania) za pomocą jej indywidualnych preferencji subiektywnych, optymalnych rozkładów uzyskanych w warunkach operacyjnej multi-alternatywności i operacyjnych alternatyw niepewności subiektywnych indywidualnych preferencji elementu aktywnego systemu. Opisane podejście uwzględnia proste dwie alternatywne sytuacje operacyjne $\mathrm{w}$ odniesieniu do obiektywnie istniejących funkcji efektywności związanych z systemem sterowania statkiem powietrznym w świetle kontrolowanego parametru i jego kombinacji Uzyskane wyrażenia dla obiektywnych funkcjonalnych ekstremalnych funkcji skuteczności i preferencji, a także subiektywna entropia preferencji alternatyw, zilustrowane na schematach, pokazują sytuację i pozwalają na dokonanie dobrego wyboru. Pomysły dotyczące wymaganej właściwej optymalizacji metod zarządzania i kontroli w odniesieniu do tylko dwóch alternatywnych argumentów funkcji efektywności celu mogą być proste - niemniej jednak zwiększenie liczby parametrów i dalsze komplikowanie problemu nie zmieni zasady rozwiązania.

Słowa kluczowe: sterowanie, nawigacja, decyzyjność, preferencje, teoria entropii. 